\title{
FAMILY MEDICAL HISTO- RY AS INSPIRATION FOR A MASTERPIECE: JAMES JOYCE'S ULYSSES
}

\section{Sonja Đurić}

Language Centre,

University of Valencia, Spain

GENTEXT Research Group,

University of Valencia, Spain

UDK: 616.895-02-036:616.895.8

\section{Summary}

The paper briefly recaps some of the most obvious examples of insanity, phobias, mental illnesses and other out of the ordinary mental states from James Joyce's Ulysses with the intention of showing the results of a literary text analysed through a medical prism. The medical history of the Joyce family is exposed in this paper with the intention of drawing parallels between reality and fiction, proving that the reality may have given inspiration for fiction. Joyce depicts a single day, 16 June 1904, in Dublin throughout 18 chapters and 732 pages. The list of diseases, phobias, mental states, addictions and other bodily troubles and misfortunes is infinite in Ulysses. The main characters Molly Bloom, Mr. Bloom, Stephen Dedalus and Gerty MacDowell as well as many others suffer from a series of medical issues. Many Joyceans suggest that Joyce found inspiration for the topics he explored in his personal life as his family members battled with phobias, sexual deviations, 
mental instability, anxiety, delirium and alcoholism. James Joyce, Nora Barnacle, Lucia and Giorgio as well as their parents, grandparents, friends, relatives and partners gave inspiration for the sexual deviations, mental instabilities, phobias and anxieties of Molly Bloom, Mr. Bloom, Stephen Dedalus and Gerty MacDowell among many other characters.

\section{Key words:}

James Joyce, Ulysses, medicine, mental instability, sexual deviations

\section{INTRODUCTION}

Literature and medicine, as it appears, often cross each other's paths. Although it seems that literature has been concerned with medicine far longer than medicine has been with literature. Nowadays in teaching medicine many resort to literature in search of vivid examples of patients and diseases and multilayered historical and social contexts ${ }^{[1]}$.

Writers such as Cervantes (in Don Quixote), Shakespeare (in King Lear), Faulkner (in The Sound and the Fury) and Virginia Wolf (in Mrs Dalloway), as many others before and after them, all employed mental illnesses in their literary works with the intention of realistically portraying their characters. However, James Joyce and his Ulysses might be best known for episodes of insanity and rich description of human experiences ${ }^{[1]}$. Joyce ventured not only into the field of psychiatry but also interwove several other branches of medicine into his masterpiece, thereby creating a medico-literary encyclopaedia of a kind ${ }^{[2]}$. His characters experience all bodily functions and needs, battle all types of insanity and diseases, discuss pains and remedies and visit the hospital on their path from conception over birth, life and death through metempsychosis. What is fascinating about Ulysses is the fact that Joyce exposed his own family's medical history in the novel. 
Even though Ulysses is abundant with all kinds of medical topics and Joyce found inspiration both within and outside his family, this paper mainly concentrates on the depictions of mental instability inspired by the Joyce family. The paper briefly recaps some of the most obvious examples of insanity, phobias, mental illnesses and other out of the ordinary mental states from Ulysses with the intention of showing the results of a literary text analysed through a medical prism.

\section{PERSONAL BACKGROUND AND LITERARY PARALLELS}

James Augustine Aloysius Joyce was born on 2 February, 1882 in Dublin, Ireland. He was the first of ten surviving children of John Stanislaus Joyce and Mary Murray. On 16 June, 1904, Joyce had his first date with Nora Barnacle (1884-1951) who immediately became his lifelong companion. The couple had two children, Giorgio (1905-1976) and Lucia (1907-1982). James Joyce died in Zurich in 1941 of a perforated ulcer.

In order to understand the connection between literature and medicine in Joyce's novels it is important to mention that he studied medicine in Dublin and Paris before he tried his luck as a writer. Nevertheless, according to Lyons, Joyce's medical knowledge came from his acquaintance with a group of med- ical students, rather than from his own studies as they were brief ${ }^{[2]}$. Some of Joyce's medical knowledge was perhaps sparked by his father who gave a try at studying medicine in Cork, but quickly dropped out ${ }^{[2]}$.

Joyce depicts a single day, 16 June 1904, in Dublin throughout 18 chapters and 732 pages. The list of diseases, phobias, mental states, addictions and other bodily troubles and misfortunes is infinite in Ulysses. For example, Gerty MacDowell is lame; Stephen Dedalus is haunted by ghosts, hallucinates and drinks heavily; $\mathrm{Mr}$ Bloom appears to be impotent, masochist, might have syphilis, also hallucinates and we know all about his bowl movements; Molly Bloom battles a number of anxieties in connection to her physical appearance and intelligence and is sexually promiscuous. In order to help his friends, Carlo Linati (1878-1949) and Stuart Gilbert (1883-1969), understand his novel, Joyce went as far as to draw two schemes in which he depicts the connections between human organs and the chapters in Ulysses ${ }^{[3]}$. The schemes are abundant with explanations and indications which disease and which organ are central for each chapter.

Many Joyceans suggest that Joyce found inspiration for the topics he explored in his personal life $\mathrm{e}^{[4,5,6]}$. Namely, his mother died in a cancer induced delirium, picking butterflies of the bed, while his father was an alcoholic ${ }^{[7]}$. He 
himself suffered from conjunctivitis and other eye illnesses which led to almost complete blindness towards the end. Moreover, he wore an eye patch and was short-sighted ${ }^{[8]}$. Many argue that he had syphilis, gonorrhoea and/or other venereal diseases and that both he and Nora were treated with mercury and arsenic, know remedies of the time for syphilis and gonorrhoea ${ }^{[9,10,11]}$. Joyce even believed that his own sexual promiscuity and acquired venereal diseases had contributed to the mental instability and overall illness of his children ${ }^{[9]}$.

In his letters to Nora, Joyce exhibits masochist and voyeuristic desires as well as a thing or two for coprophilia, dirty talk and fetishism altogether ${ }^{[5,6]}$. Throughout the texts of the letters Joyce does not withhold any of his sexual fantasies and nothing is left unsaid or repressed. In addition, Joyce, much like his father and son was in the habit of heavy drinking. Once Ulysses was published and the psychotic, hallucinations of the "Circe" chapter, along with all the other phobias and deviations saw the daylight, Joyce's mental state was given another look and he was considered both genius and $\operatorname{mad}^{[1,7]}$. Carl Jung was one of those who believed Joyce was mad, especially after having read Ulysses and having treated Lucia ${ }^{[7]}$.

According to Kaplan, the Joyce family did not have a history of psychiatric illnesses. However, Joyce's paternal grandmother, Ellen O’Connell, was “un- usually sensitive, delicate and anxious about her health" ${ }^{[7]}$. Joyce, too, was anxious, sensitive and fanatically superstitious, socially phobic and a hypochon$\operatorname{driac}^{[7,12]}$. The inspiration for phobias Joyce probably found in his fear of dogs, thunder, lighting and water (cynophobia and keraunophobia) ${ }^{[7]}$. Allegedly, he was attacked by a neighborhood dog when he was young and a religious aunt told him that thunder was God's anger ${ }^{[13]}$. According to LeBlanc, agoraphobia is present in Joyce's Dubliners in the story "Eveline" ${ }^{[14]}$. Nevertheless, it also appears that Mr. Bloom may suffer from agoraphobia in the "Circe" chapter of Ulysses. At first, Mr. Bloom expresses a high level of discomfort and is embarrassed, fearing that he might be seen and recognised in the brothel. Although he wants to escape the sinister place at the beginning, expressing even signs of agoraphobia, he gradually becomes more and more relaxed and in the end enjoys.

It may be argued that the character of Molly Bloom was shaped to resemble Nora $^{[15]}$, Evidence for such claims can be found in the letters Joyce and Nora exchanged $^{[5,6]}$. Unfortunately, some of Nora's letters seem to be lost. Thus what can be found in Nora's answers is not as open-minded as Molly Bloom's thoughts and her sexual appetite is not as copious as Molly Bloom's, although it certainly is sexual. When Nora was asked about the resemblance all she said was that she was much slimmer than Molly ${ }^{[16]}$. It should 
be noted that Nora ran away with Joyce in 1904. The couple moved to the continent and lived for over thirty years out of wedlock. Therefore, Nora was not a typical Irish Catholic girl.

Joyce's daughter Lucia was found mentally ill and in the 30s she was permanently hospitalized. Lucia was described as violent, aggressive; she liked setting things on fire and was even briefly and unsuccessfully treated by Carl Jung, who was her twentieth doctor ${ }^{[4,7}$, ${ }^{17]}$. Additionally, Lucia appears to have had quite an adventurous and promiscuous sexual youth which may have resulted in two abortuses. Samuel Beckett and Alexander Calder were among her lovers ${ }^{[7,17]}$. Most diagnosed that Lucia has suffered from hebephrenic schizophrenia ${ }^{[7]}$, although other interpretations of her mental instability were given. Joyce refused to come to terms with Lucia's bleak diagnosis and was convinced that she possessed a fire inside herself. What Joyce saw in his daughter was talent, creativity and passion ${ }^{[17]}$. Even though many considered Joyce to be schizophrenic or psychotic - Carl Jung being one of them - it appears that Lucia inherited her mental illness from her mother's side of the family as several relatives were treated for serious mental illnesses ${ }^{[7]}$.

Sadly, Joyce's worries did not end with Lucia. Namely, his daughter-inlaw (Girgio's wife) had a nervous breakdown, was found manic depressive and was also hospitalised ${ }^{[7]}$, while Giorgio himself battled with alcoholism ${ }^{[4,17]}$. As it appears the talented and artistic Joyce children lived in the shadows of their much famous father, depressed, misunderstood and prone to mental instability $^{[7]}$. However, their misfortunes seem to have provided the bedrock for the foundation of Ulysses.

In Ulysses, its main characters are troubled by numerous diseases and body issues. According to George, " $\mathrm{Ul}$ ysses presents non-reproductive sexual acts" most of which are especially familiar to Mr. Bloom and Molly Bloom ${ }^{[18]}$. Mr. Bloom, as we find out in the "Circe" chapter, could be suffering from epilepsy, inherited from his grandfather Virag. Virag committed suicide, which suggests that he had depression at least, if not other mental illnesses. In addition, Mr. Bloom has voyeuristic tendencies, which we find out from the "Nausicaa" chapter in which he watches young Gerty MacDowell and pleases himself. From his letters to Marta Clifford and his experience in the brothel we find out that he is a masochist too. Molly Bloom tells us that her husband is impotent, into fetishes, onanism, cunnilingus, fellatio, pornography and coprophilia. Throughout the "Penelope" chapter, Molly Bloom recalls all the sexually deviant intercourses she and her husband indulged in. In the brothel scenes of "Circe", Mr. Bloom's nympholepsy, transvestism, homosexuality, androgy- 
ny, bisexuality, cuckoldry and connivance in cuckoldry all become apparent. Furthermore, Mr. Bloom hallucinates and shows signs of psychosis.

Gerty, appears to be narcistic, and obsessively compulsive when it comes to her looks and underwear. Additionally, Gerty puts on an exhibitionist performance for Mr. Bloom. Molly Bloom, herself also prefers some unconventional sexual intercourses. She does not oppose to doing whatever her loves ask of her, she even has an idea or two of her own and appears rather keen on having sexual intercourse in public places. She seems melancholic, hypochondriac and has several body issues. She resorts to remedies and tricks to lose weight and enhance her breasts.

Stephen Dedalus is haunted by ghosts and guilt. He hallucinates and drinks heavily. In addition, he too is melancholic and depressed. He is often acquainted by prostitutes and evidently suffers from venereal diseases. Stephen Dedalus is portrayed as James Joyce's alter ego and hence mirrors many of Joyce's characteristics, one of which could be social phobia.

\section{CONCLUSION}

Certain parallels between the medical history of the Joyce family and the health issues of the characters from Ulysses are drawn throughout this paper. Joyce found inspiration in everything that surrounded him from art, literature, music, history, politics and mythology to medicine. However, it appears that his own health and the health of his closest family members allowed him to portray deeply troubled characters in Ulysses. James Joyce, Nora Barnacle, Lucia and Giorgio as well as their parents, grandparents, friends, relatives and partners gave inspiration for the sexual deviations, mental instabilities, phobias and anxieties of Molly Bloom, Mr. Bloom, Stephen Dedalus and Gerty MacDowell among many other characters. 


\section{PORODIČNA ANAMNEZA KAO INSPIRACIJA ZA REMEK DELO: ULIKS DŽEJMSA DŽOJSA}

\section{Sonja Đurić}

Centar za jezike,

Univerziet u Valensiji, Španija

GENTEXT istraživačka grupa,

Univerziet u Valensiji, Španija

UDK: 616.895-02-036:616.895.8

\section{Kratak sadržaj}

U ovom radu se ukratko pominu neki za fikciju. Džojs opisuje jedan dan, 16. juna 1904. godine u Dablinu kroz 18 poglavlja i na 732 strane. Lista bolesti, fobija, mentalnih stanja, zavisnosti i između realnosti i fikcije, dokazujući da je stvarnost mogla da da inspiraciju drugih telesnih problema i nesreća je beskonačna u Uliksu. Glavni likovi Moli Blum, gospodin Blum, Stefan Dedalus i Gerti MekDovel, kao i mnogi drugi pate od niza medicinskih problema. Mnogi Džojsovci sugerišu da je Džojs pronalazio inspiraciju za teme koje je istraživao u svom ličnom životu, jer su se njegovi članovi porodice borili protiv fobija, seksualnih devijacija, mentalne nestabilnosti, anksioznosti, delirijuma i alkoholizma. Džejms Džojs, Nora Barnakl, Lusija i Džiordžio, kao i njihovi roditelji, prijatelji, rođaci i partneri dali su inspiraciju za seksualne devijacije, mentalne nestabilnosti, fobije i anksioznosti Moli Blum, g. Bluma, Stefana Dedalusa i Gerti MakDovel među mnogim drugim likovima.

\section{Ključne reči:}

Džejms Džojs, Uliks, medicina, mentalna nestabilnost, seksualne deviacije 


\section{LITERATURE / LITERATURA}

1. Shanahan F., Quigley EM, Medicine in the Age of "Ulysses": James Joyce's portrait of life, medicine, and disease on a Dublin day a century ago.

Perspectives in biology and medicine, 2006: 49(2) 27685.

2. Lyons JB, James Joyce and Medicine. Dublin: Dolmen Press, 1973.

3. Ellmann R, Ulysses on the Liffey, Oxford University Press, 1986: 186190.

4. Norris M, eds. A Companion to James Joyce's Ulysses. Boston and New York: Bedford Books 1998.

5. Ellmann R, eds. Letters of James Joyce. Vols. I and II. New York: Viking 1966.

6. Ellmann R, ed. James Joyce, Selected Letters of James Joyce. New York/ London: Viking/Faber 1975.

7. Kaplan R, Madness and James Joyce. Australasian Psychiatry, Psychiatry and the arts 2002; 10 (2): 172176.

8. Paris J, Joyce. Trans. Sonja Šešlija. Novi Sad and Belgrade: IK "Kiša" 2012.

9. Ferris K, James Joyce and the Burden of Disease. Lexington, Kentucky: The University Press of Kentucky 2010.

10. Baron JH, Illness and creativity: Byron's appetites, James Joyce's gut, and Melba's meals and misalliances. BMJ 1997; 315: 16971703.

11. Ellmann R, James Joyce, rev. ed. Oxford: Oxford University Press 1982.

12. Birmingham $K$, The Most Dangerous Book: The Battle for James Joyce's Ulysses. London: Penguin Press 2014. 13. Thakur P, The Most Important People of the 20th Century - II. Artists and Entertainers. Punjab: Pradeep Thakure \& Sons 2010.

14. LeBlanc J, Agoraphobia in James Joyce's - Eveline. Papers on Joyce 16 (2010): 2947.

15. Maddox B, Nora: The Real Life of Molly Bloom. Boston and New York: A Mariner Book, Houghton Mifflin Company 1988.

16. De Grazia E, Girls Lean Back Everywhere: The Law of Obscenity and the Assault on Genius. Cardozo Arts \& Entertainment 1991; 9: 387438.

17. Loeb Shloss C, Lucia Joyce. To Dance in the Wake. London: Picador 2005.

18. George JM, Ulysses Quotidianus: James Joyce's Inverse Histories of the Everyday. Newcastle upon Tyne: Cambridge Scholars Publishing 2016.

\section{Sonja Đurić}

Calle Salvador Rodriguez

Bronchu $1 \mathrm{~K}$ pta 15

46025, Valencia, Spain

Tel.fax.mob: + 34672359868

dj_sonjica@yahoo.com 